\title{
Anticancer Activity of Acetogenins from Annona Muricata Fruit
}

\author{
Djabir Daddiouaissa ${ }^{a}$ \& Azura Amid ${ }^{b}$
}

${ }^{a}$ Kulliyyah of Engineering, International Islamic University Malaysia (IIUM), Jalan Gombak, 53100 Kuala

Lumpur, MALAYSIA

${ }^{b}$ International Institute for Halal Research and Training (INHART), Level 3, KICT Building, International Islamic University Malaysia (IIUM), Jalan Gombak, 53100 Kuala Lumpur, MALAYSIA

\begin{abstract}
Medicinal plants become very important in our days for their therapeutic benefits to humankind. It sustains human health, and it is commonly known as herbal medicines since ancient times. Annona muricata is a heart-shaped fruit that is consumed raw or as the fruit juice in the tropical area. A. muricata is used in traditional and alternative medicine to treat different ailments such as diabetes, hypertension, respiratory and skin illness, inflammation and cancer. A. muricata contains essential anticancer agents named acetogenins that play the significant role in various cancer types. Acetogenins are strong nicotinamide adenine dinucleotide oxidase inhibitors of the cancer cell's mitochondrial membrane but showed neurotoxic effects in rats. Therefore, acetogenins need to be further investigated to determine the exact mechanisms of action, long-term safety, optimal dosage, and potential side effects. Given the extensive studies on $A$. muricata, this review focuses on the phytochemistry, medicinal uses, biological activities and the mechanisms of action for the fruit extracts and acetogenins, to stimulate further studies on the fruit pulp used for human consumption.
\end{abstract}

KEYWORDS: Acetogenins, Anticancer, Annona muricata, complex I mitochondrial.

\section{INTRODUCTION}

Natural products from plants have been used for a considerable period by many cultures and civilizations to help humankind maintain its health and treat different diseases. Over the centuries, the phytochemical compounds have been an essential discovery in pharmaceutical applications. The significance of the active compounds from plants in medicine and agriculture has stimulated scientific interest in its biological properties. ${ }^{1}$ In a pharmaceutical area, plants used in ethnomedicine are the most abundant source of active phytochemicals that afford health benefits against different ailments and diseases. One of it with many

Corresponding Author:

Prof. Dr. Azura Amid

Institute for Halal Research and Training (INHART),

Level 3, KICT Building,

International Islamic University Malaysia,

Kuala Lumpur, Malaysia

Email: azuraamid@iium.edu.my traditional uses is Annona muricata L. ${ }^{2}$ A. muricata is a species in the Annonaceae family that obtained much interested in the last decades due to its pharmaceutical potential. A long time ago, many studies reported on the medicinal use of the Annonaceae family, since then, the bioactivity and toxicity of this species attracted the attention of many researchers. ${ }^{2,3}$ Among the critical subject studied related to $A$. muricata is its acetogenins. This study will extensively collect relevant information regarding $A$. muricata acetogenins to identify the uncover information so that further investigation will be made.

\section{BOTANICAL DESCRIPTION AND DISTRIBUTION}

A. muricata is commonly known as soursop (English), graviola (Portuguese), guanabana (Latin; South America) and many other indigenous names. This plant species belongs to the genus of Annona and the Annonaceae family; the order of Magnoliales and Magnoliophyta Division. ${ }^{4}$ The Annona genus contains 
more than 70 species in which $A$. muricata is widely grown. ${ }^{3} A$. muricata distributes in the warmest tropical region of Central and South America, Southeast Asia and Western Africa. ${ }^{4}$ It grows at altitudes below $1200 \mathrm{~m}$ above sea level, and temperatures between 25 and $28{ }^{\circ} \mathrm{C}$, with humidity between 60 and $80 \%$ and annual precipitation over $1500 \mathrm{~mm}$.

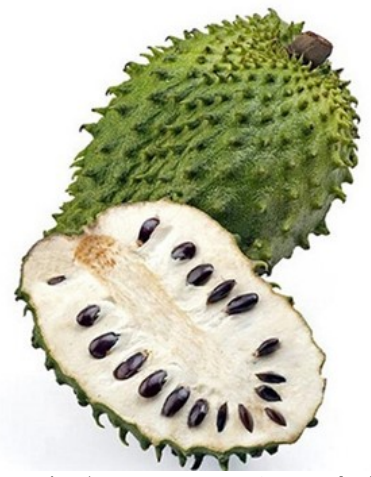

Figure 1. Annona muricata $L$ fruit

A. muricata is a 4 to 6 meters high evergreen tree with large, glossy, dark green leaves. ${ }^{1}$ Its edible fruits are large, heart-shaped, dark green in color, with a diameter which varies between $5-20 \mathrm{~cm}$ and an average weight of 0.4 to $1.0 \mathrm{~kg}$ (Figure 1). Each fruit may include 55-170 black seeds. ${ }^{4}$ The pulp of the fruit has a sweet flesh, and typical flavor which can be eaten and used as an ingredient in the preparation of many foods and is perfect for making drinks, candy and ice cream. Also, the edible fruit, leaves, seeds, and root are known to have attractive medicinal properties. ${ }^{5}$

\section{ETHNO MEDICINAL USE}

All portions of $A$. muricata tree such as leaves, twigs, fruit, and seeds are used against many human ailments and diseases, particularly cancer and parasitic infection. ${ }^{6}$ The fruit is taken as herbal medicine to eliminate worms and parasites, for arthritic pain, diarrhea, neuralgia, dysentery, rheumatism, cold fever and to increase mother's milk after childbirth. ${ }^{7}$ Table I lists the ethnomedicinal use of $A$. muricata fruit.

Table I: Ethnomedicinal use of $A$. muricata fruit in the world

\begin{tabular}{|c|c|c|c|}
\hline $\begin{array}{l}\text { Worldwide } \\
\text { ethnomedicinal use }\end{array}$ & Ethnomedicinal use & $\begin{array}{l}\text { Preparation/ } \\
\text { application }\end{array}$ & References \\
\hline Bolivia & Kidney disorders, hypertension & Juice/oral & 10 \\
\hline Brazil & Lactagogue, astringent, diarrhea, dysentery & Juice/oral & 8 \\
\hline Colombia & Febrifuge, inflammation & Juice/oral & 11 \\
\hline The Dominican Republic & Galactogogue & Infusion/oral & 12 \\
\hline Haiti & $\begin{array}{l}\text { Fevers, flu, heart affectation parasite, } \\
\text { pellagra, anxiety, febrifuge, diarrhea, and } \\
\text { lactagogue }\end{array}$ & NR & 8 \\
\hline Jamaica & Fevers, parasites, diarrhea, and lactagogue & Juice/oral & 13 \\
\hline Malaysia & Stomach pain, hypertension & Juice/oral & 14 \\
\hline Mexico & Dysentery, diabetes & Juice/oral & 15 \\
\hline The Philippines & Diabetes & Pulp/oral & 8 \\
\hline Peru & $\begin{array}{l}\text { Obesity, gastritis, dyspepsia, diabetes, } \\
\text { inflammation, and cancer }\end{array}$ & Pulp, juice/ oral & 8 \\
\hline Uganda & Diabetes & Pulp/oral & 16 \\
\hline West Indies & $\begin{array}{l}\text { Fevers, parasites, diarrhea, and } \\
\text { galactagogue }\end{array}$ & Poultice/oral & 13 \\
\hline
\end{tabular}


Recently, A. muricata fruit consumption increased. ${ }^{11}$ Researchers identified bioactive compounds such as acetogenins and polyphenols in its pulp, which are related to different pathology prevention including neurodegeneration, diabetes, cardiovascular and anti-inflammatory diseases. ${ }^{8}$ At present, the attention is being focused on anticancer properties of $A$. muricata acetogenins which are the primary bioactive compounds found in the fruit. ${ }^{9}$

\section{PHYTOCHEMICALS}

A. muricata flesh fruit consists of $80 \%$ water, $18 \%$ carbohydrates, $1 \%$ protein and small quantities of vitamins B, B2, C and dietary fiber. ${ }^{17} A$. muricata fruit contains various significant minerals too, such as potassium $(\mathrm{K})$, calcium $(\mathrm{Ca})$, sodium $(\mathrm{Na})$, copper $(\mathrm{Cu})$, iron $(\mathrm{Fe})$ and magnesium $(\mathrm{Mg})$. Because of its nutritional values, Gymfi and co-workers (2011) suggested that the $A$. muricata fruit can provide essential elements and nutrients to the human body. ${ }^{18}$
Many phytoconstituents and compounds found in different parts of $A$. muricata, including alkaloids (ALKs), phenolics (PLs), megastigmanes (MGs), flavonol triglycosides (FTGs), cyclopeptides (CPs) and essential oils. ${ }^{1}$ Additionally, A. muricata has shown to be the most abundant source of the annonaceous acetogenin compounds (AGEs), in which, researchers have identified more than 120 acetogenins from methanolic, ethanolic or another organic extract of different part of $A$. muricata such as leaves, seeds, bark, stems, pulp and fruit peel..$^{20,21}$

\section{ANNONACEOUS ACETOGENINS}

Acetogenins are secondary metabolites of C35/C37 deriving from the long chain of unsaturated fats in the polyketide pathway. A methyl-substituted a, Bunsaturated $\gamma$-lactone form them, which is usually combined with fatty acids with a two-propanol unit at C-2 (Figure 2). ${ }^{20,22}$

$$
\overbrace{O=1}^{2}
$$

Figure 2: General structure of acetogenins.

AGEs are the main bioactive compounds of the Annonaceae family. ${ }^{23}$ Since 1982 when Jolad et al. discovered uvaricin from Uvaria accuminata, more than 500 AGEs have been identified from various parts of plants in the Annonaceae family. ${ }^{24}$ In recent years, many scientific studies focused on AGEs because of their unusual structures and extensive biological activities. Some studies have shown that AGEs are more cytotoxic than alkaloids and rotenone. $^{3}$

The biological activities of AGEs, which are known as anticancer are initially by inhibiting the complex I mitochondrial of the cell (mitochondrial NADH: ubiquinone oxidoreductase). ${ }^{25}$ Biological studies and phytochemical investigations of the A. muricata fruit brought a wide range of AGE compounds, as summarized in Table II.

The chemical structures of the essential AGEs extracted from $A$. muricata fruit were shown in Figure 3. To the best of our knowledge, at the time of preparation of this paper (May 2018), at least 20 AGEs have been identified and isolated from the $A$. muricata fruit pulp. 
Table II: Annonaceous acetogenins extracted from A. muricata fruit (AGE) and its biological activities.

\begin{tabular}{|c|c|c|c|c|}
\hline Compounds & $\begin{array}{l}\text { Stage of } \\
\text { study }\end{array}$ & Biological Activity & $\begin{array}{l}\text { Mechanism of } \\
\text { action }\end{array}$ & References \\
\hline $\begin{array}{l}\text { Annonamuricin A, } \\
\text { B, C, D }\end{array}$ & In vitro & $\begin{array}{l}\text { Inhibition of human prostate cancer } \\
\text { PC-3 cells }\end{array}$ & NR & 9 \\
\hline Annonacin & In vitro & Inhibition of PC -3 cells & NR & 9 \\
\hline Muricin $M$ & In vitro & Inhibition of PC -3 cells & NR & 26 \\
\hline Muricin N & In vitro & Inhibition of PC -3 cells & NR & 26 \\
\hline Muricenin & In vitro & Inhibition of PC-3 cells & NR & 26 \\
\hline Muricin $\mathrm{J}$ & In vitro & Inhibition of PC -3 cells & $\begin{array}{l}\text { Inhibition of the } \\
\text { complex I } \\
\text { mitochondrial. } \\
\text { Inhibition of the }\end{array}$ & 27 \\
\hline Muricin $\mathrm{K}$ & In vitro & Inhibition of PC-3 cells & $\begin{array}{l}\text { complex I } \\
\text { mitochondrial. }\end{array}$ & 27 \\
\hline Muricin L & In vitro & Inhibition of PC-3 cells & $\begin{array}{l}\text { Inhibition of the } \\
\text { complex I } \\
\text { mitochondrial. }\end{array}$ & 27 \\
\hline $\begin{array}{l}\text { Annoreticuin-9- } \\
\text { one }\end{array}$ & In vitro & $\begin{array}{l}\text { Cytotoxicity against human } \\
\text { pancreatic tumor (PACA-2), lung } \\
\text { carcinoma (A-549) and prostate } \\
\text { adenocarcinoma (PC-3) cell lines }\end{array}$ & NR & 20 \\
\hline Cis-annoreticuin & In vitro & $\begin{array}{l}\text { Cytotoxicity against human } \\
\text { hepatoma cell line (Hep G2) }\end{array}$ & NR & 20 \\
\hline Sabadelin & -- & NR & NR & 20 \\
\hline Epomuricenins-A & -- & NR & NR & 28 \\
\hline Epomuricenins-B & -- & NR & NR & 28 \\
\hline Epomusenin-A & -- & NR & NR & 28 \\
\hline Epomusenin-B & -- & NR & NR & 28 \\
\hline Epomurinin-A & -- & NR & NR & 28 \\
\hline Epomurinin-B & -- & NR & NR & 28 \\
\hline
\end{tabular}

\section{Anticancer Activity and Mechanism of Action of Acetogenins}

Cancer is among the most common causes of morbidity and mortality in the world, about 1.73 million new cancer cases and 609,640 cancer deaths are projected to occur in the United States in 2018. ${ }^{29}$ Many studies reported on the significance cytotoxicity of different extracts and isolated AGEs from a different part of $A$. muricata towards various cancer cell lines. ${ }^{30,31}$ However, few of these studies have illustrated or focus on the benefits of the fruit pulp against cancer disease. Mainly, the acetogenins extracted from the fruit pulp of $A$. muricata and its mechanism of actions.
Previous data reported that $A$. muricata has an ability on growth inhibition against a wide variety of cancer cells, including solid breast tumor, lung carcinoma cell lines, prostate adenocarcinoma, colon adenocarcinoma cell lines. As well as on pancreatic carcinoma cell lines, human lymphoma cell lines, liver cancer cell lines and multi-drug resistant human breast adenocarcinoma. ${ }^{32,33}$

Among many active ingredients, acetogenins modulate the production of mitochondrial adenosine triphosphate (ATP) of cancer cells. ATP reduces the nourishment of cancer cells by decreasing the growth of blood vessels. Previous studies have proposed that the mechanism of the cytotoxic action of acetogenins is the inhibition of the 
mitochondrial complex $\mathrm{I}$ by the inhibition of ubiquinone-linked NADH oxidase in the membrane causing apoptosis in cancer cells. ${ }^{34,35}$

Complex I, the most complicated proton pump of the respiratory chain encoded by the nuclear and mitochondrial genomes, which is responsible for NADH oxidation, the hydrogenase of released electrons to electron acceptor ubiquinone and the proton translocation module. ${ }^{36}$ Inhibition of complex I diminish NADH oxidation which lowers the proton gradient through the internal mitochondrial membrane and the ATP synthesis. Moghadamtousi et al. have confirmed it by demonstrating that the extracts of $A$. muricata can arrest cancer cells development in $\mathrm{G} 0 / \mathrm{G} 1$ phase which caused by the disruption of the mitochondrial membrane, and the induction of apoptosis to suppress the invasion and migration of cancer cells. ${ }^{37}$

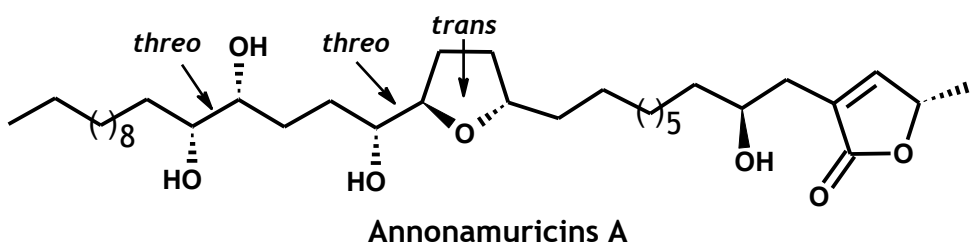

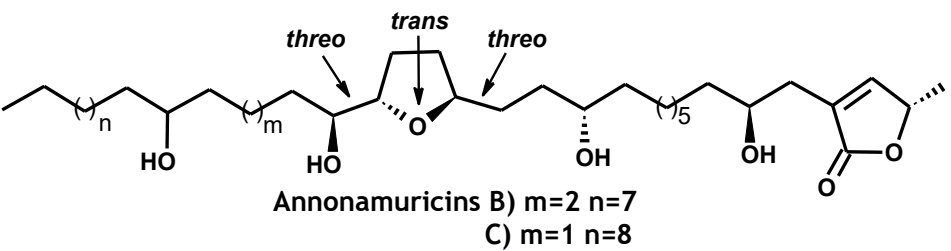<smiles>CCCCCC(O)C1CC[C@@H](C(C)CCC(O)CC[C@@H](O)CC2=C[C@@H](C)OC2=O)O1</smiles>

Annonamuricins D

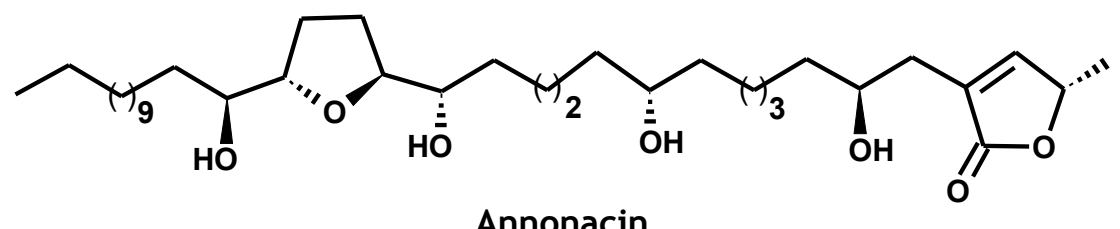

Annonacin

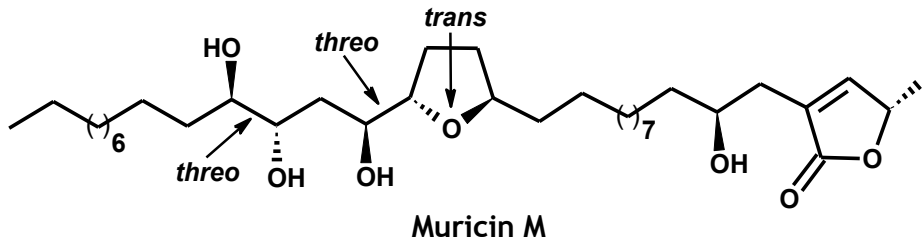



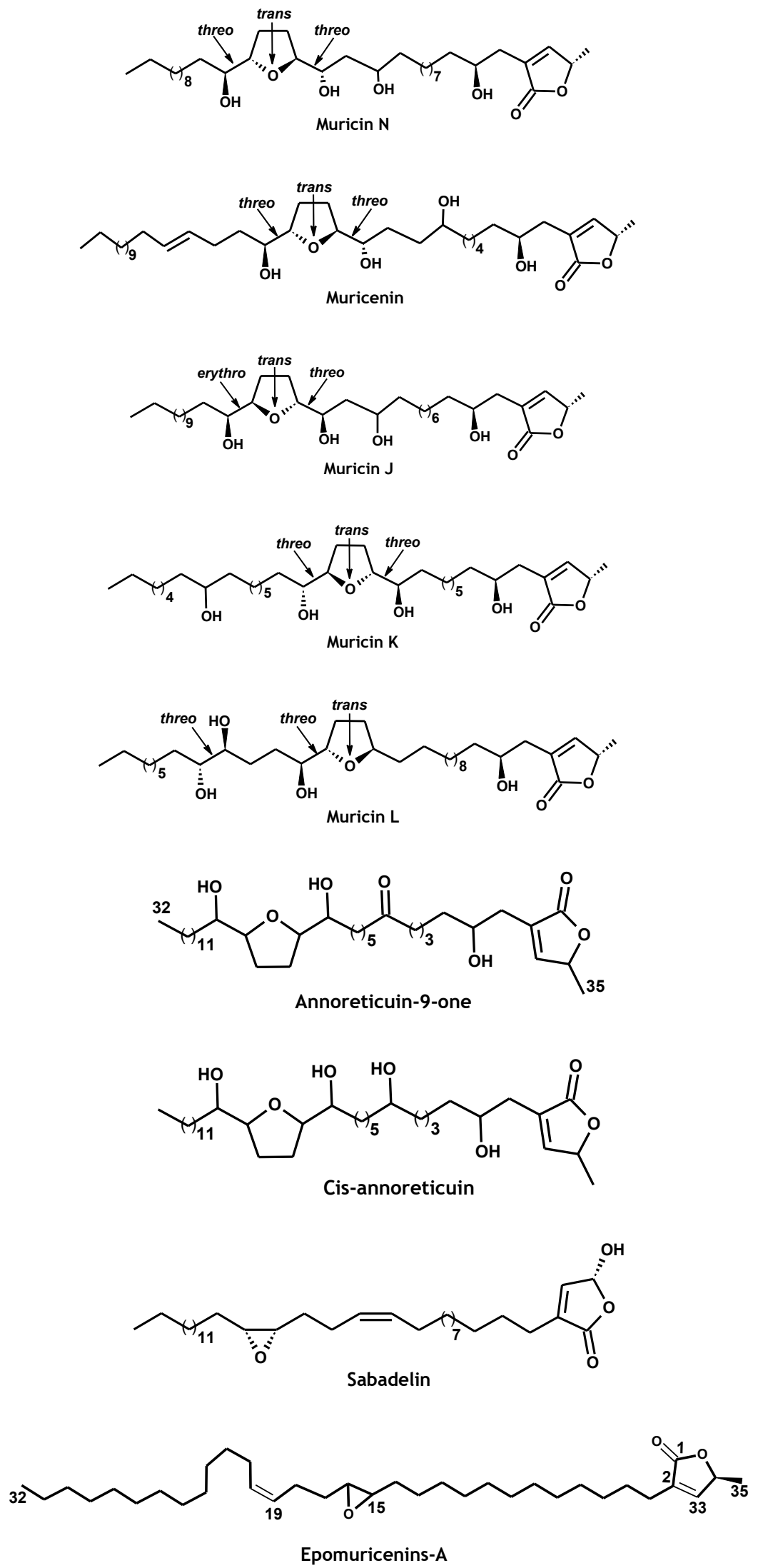
<smiles>CCCCCCCCCCCCCC=CP=CCCC1OC1CCCCCCCCCCC1=CC(C)OC1=O</smiles>

Epoxymurin-A

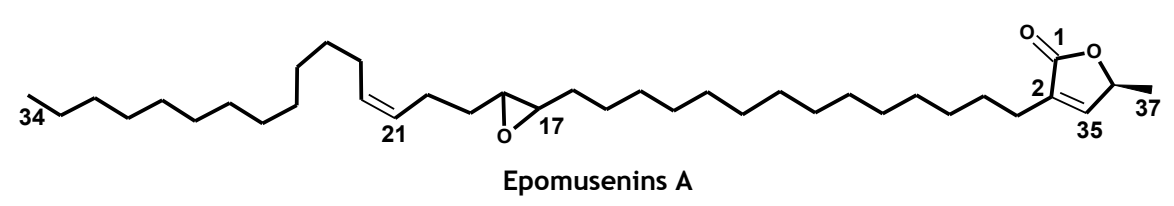<smiles>[B]C1C=C(CCCCCCCCCCCC[C@@H]2O[C@@H]2CCC/C=C\CCCCCCCCCCCCCCCC)C(=O)O1</smiles><smiles>CCCCCCCCCCCCCCCCC1OC1CCCCCCCCCCCCC1=C[C@H](C)OC1=O</smiles><smiles>CCCCCCCCCCCCCCCCCCC1OC1CCCCCCCCCCCC1=C[C@H](C)OC1=O</smiles>

Figure 3: Chemical structures of the major acetogenins isolated from $A$. muricata fruit.

Moreover, the complex I dysfunction provoke the activation of the mitochondrial-dependent apoptotic machinery via triggering liberation of apoptogenic molecule cytochrome $\mathrm{c}$ from defective mitochondria. ${ }^{36}$ Another study reported that Annomuricin E caused depletion of mitochondrial membrane potential (MMP) which leads to the formation of apoptosome and the activation of caspase 9 and caspase $3 / 7$, which have a relation with mitochondrial death pathway. ${ }^{38}$ Additionally, Annonacin $\mathrm{E}$ upregulated Bax protein and downregulates $\mathrm{Bcl}-2$ proteins. This result confirms that Annonacin E caused apoptosis through the mitochondrial-mediated pathway. The AGEs apoptosis effect is selective for cancer cells is related to high ATP demand in cancer cells as suggested by McLaughling that selective cytotoxicity of $A$. muricata extracts is because of the enhanced ATP request of tumor cells compared to the healthy cells. ${ }^{39}$

In vivo studies reported the anticancer activity of isolated acetogenins from $A$. muricata fruit reduced a breast tumor in rats when treated with $A$. muricata fruit extract for 5 weeks. ${ }^{40}$ Many mechanisms of action of the cytotoxicity of $A$. muricata were suggested including the inhibition of multiple signaling pathways, metastasis, cell cycle arrest and induction of necrosis. ${ }^{33,40} \mathrm{Ko}$ and coworkers also reported that bullatacin extracted from A. muricata at doses of $0.4 \mathrm{~g} / \mathrm{kg}$ could reduce a tumor induced in rodents 300 times better than the drug Taxol (paclitaxel). ${ }^{41}$ Meanwhile, Wang and coworkers reported that annonacin decreased tumour size in murine models at doses of $0.01 \mathrm{mg} / \mathrm{kg}$ compared to the commercial drugs such as adriamycin and cisplatin. ${ }^{42}$

Although there are many AGEs isolated and identified from $A$. muricata fruit, there is insufficient understanding of its mechanisms of action in reducing tumor or cancer cells. ${ }^{20,21}$ Therefore, more study is needed to understand how AGEs work entirely. These significance anticancer and antitumor activities selected for A. muricata is due to the active compounds, especially AGEs that can be utilized as a cancer adjuvant treatment. ${ }^{30}$

\section{Study on Neurotoxin Effect of Acetogenins}

The dysfunction of mitochondrial $\mathrm{Cl}$ relates to a wide range of neurodegenerative diseases. ${ }^{36} \mathrm{~A}$ published study in the Lancet Journal in 1999 investigated the 
relationship between the consumption of $A$. muricata fruit and the occurrence of atypical parkinsonian syndromes observed in the French West Indies on 87 patients. $^{43}$ Furthermore, the etiology of that disease in Guadeloupe Island showed a close correlation between acetogenins consumption and appearance of the neurodegenerative illness. ${ }^{44}$ A recently published study reported that annonacin as a significant $A G E$ in $A$. muricata might be a potential risk factor for neurodegenerative diseases. ${ }^{45}$ In rodent striatal neurons, annonacin minimized the ATP supply and interrupted the mitochondrial transportation to the cell soma; this caused perturbations in the protein tau which led to similar characteristics of neurodegenerative diseases. ${ }^{44}$ It is anticipated that if somebody consumes one fruit of $A$. muricata daily, following one year, the aggregate amount of annonacin that has ingested is adequate to induce brain lesions in rats. ${ }^{46}$

However, the number of the human population studied and the study in the rat may not represent a broader community of human in another area or continents. Because A. muricata is not new to those in warm tropical regions and a study by Muangpaisan and co-workers showed that the prevalence of Parkinson's diseases in Asian countries was slightly lower than that in Western nations, although $A$. muricata consumption is a routine practice among this people. ${ }^{47}$ Despite some in vitro and in vivo studies reported on its neurotoxic compounds, Awodele and co-workers demonstrated that consumption of $A$. muricata fruit for 60 consecutive days did not induce any significant toxicity in a rat model. ${ }^{48}$ Therefore, an in-depth study on the mechanism of action in vitro and in vivo and optimize consumption dosage at a specific AGEs must be carried out.

\section{CONCLUSION}

A. muricata fruit, an indigenous medicinal plant used for ages to treat many diseases. Many types of research have proven that $A$. muricata possesses a wide range of biological activities, and the most likely are anticancer, antidepressive and antiparasitic activity. However, there are limited studies on $A$. muricata phytoconstituents and compounds, especially acetogenins reported on its cytotoxic to the cancer cells especially on its mechanism of actions. Nevertheless, it is also said to have a neurotoxic effect.
More research is needed to identify AGEs mechanism of actions and quantify the neurotoxic molecules effects and determine the toxicity level to human. Finally, more clinical studies are required to verify and validate the plant extracts safety, to be adopted as a therapeutic anticancer agent.

\section{REFERENCES}

1. Moghadamtousi SZ, Fadaeinasab M, Nikzad S, et al. Annona muricata (Annonaceae): A review of its traditional uses, isolated acetogenins, and biological activities. International Journal of Molecular Sciences 2015a;16(7):15625-15658.

2. Billo' $\mathrm{nH}$. Histoire des plantes. Librairie de L. Hachette, Paris 1869 ; pp. 275-276.

3. Coria-Téllez AV, Montalvo-Gónzalez E, Yahia EM, et al. Annona muricata: A comprehensive review of its traditional medicinal uses, phytochemicals, pharmacological activities, mechanisms of action and toxicity. Arabian Journal of Chemistry 2015.

4. Pinto $\mathrm{AC}$, de $\mathrm{Q}$, Cordeiro $\mathrm{MCR}$, et al. Annona muricata. In: Williams, J.T. (Ed.), Annona species, taxonomy and botany international centre underutilised crops. University of Southampton, Southampton, UK 2005; pp. 316.

5. Ioannis $P$, Anastasis $S$, and Andreas $Y$. Graviolaa: A systematic review of Its aticancer properties 2015;3(6):128-131.

6. Gajalakshmi S, Vijayalakshmi S, Rajeshwari Devi V. Phytochemical and pharmacological properties of Annona muricata: A review, Int J Pharm Sci 2012;4(2):3-6.

7. Yajid Al, Ab Rahman HS, Wong MPK, et al. Potential benefits of Annona muricata in combating cancer: A review. The Malaysian journal of medical sciences: MJMS 2018;25 (1):5.

8. Badrie N, and Schauss AG. Soursop (Annona muricata L.): composition, nutritional value, medicinal uses, and toxicology. Bioactive Foods in Promoting Health 2010;621-643.

9. Sun S, Liu J, Sun X, et al. Novel Annonaceous acetogenins from Graviola (Annona muricata) fruits with strong anti-proliferative activity. Tetrahedron Letters 2017;58(19):1895-1899.

10. Hajdu Z, and Hohmann J. An ethnopharmacological survey of the traditional medicine utilized in the community of Porvenir, Bajo Paraguá Indian Reservation, 
Bolivia. Journal of Ethnopharmacology 2012;139(3):838-857.

11. Betancur-Galvis LA, Saez J, Granados H, et al. Antitumor and antiviral activity of Colombian medicinal plant extracts. Memórias do Instituto Oswaldo Cruz 1999;94(4):531-535.

12. Ross IA. Medicinal plants of the world, second ed. Chemical Constituents, Traditional and Modern Medicinal 2010; 1:133-142.

13. Taylor L. Graviola. Technical data report for Graviola, Annona muricata, 2002.

14. Samuel AJSJ, Kalusalingam A, Chellappan DK, et al. Ethnomedical survey of plants used by the Orang Asli in Kampung Bawong, Perak, West Malaysia. Journal of Ethnobiology and ethnomedicine 2010;6(1):5.

15. Alonso-Castro AJ, Villarreal ML, Salazar-Olivo LA, et al. Mexican medicinal plants used for cancer treatment: pharmacological, phytochemical and ethnobotanical studies. Journal of Ethnopharmacology 2011;133 (3):945-972.

16. Ssenyange CW, Namulindwa A, Oyik B, et al. Plants used to manage type II diabetes mellitus in selected districts of central Uganda. African health sciences 2015;15 (2):496-502.

17. Pier 0. Pacific island ecosystem at risk, "Result set for Annonaceace Annona muricata." United States Geological Survey and the United States Forest Service: Pier species lists, 8, 2008.

18. Gyamfi K, Sarfo D, Nyarko B, et al. Assessment of elemental content in the fruit of the graviola plant, Annona muricata, from some selected communities in Ghana by instrumental neutron activation analysis. Elixir Food Sci 2011;41:5671-5675.

19. Leboeuf M, Cavé A, Bhaumik PK, et al. The phytochemistry of the Annonaceae. Phytochemistry 1980;21 (12):2783-2813.

20. Ragasa CY, Soriano G, Torres OB, et al. Acetogenins from Annona muricata. Pharmacognosy Journal 2012;4 (32):32-37.

21. Champy $P$, Gue' rineau V, and Lapre' vote 0 . MALDI-TOF MS Profiling of Annonaceous Acetogenins in Annona muricata products for human consumption. Molecules 14 2009; 52355246.

22. Bermejo A, Figadère $B$, Zafra-Polo $M C$, et al.
Acetogenins from Annonaceae: recent progress in isolation, synthesis and mechanisms of action. Natural Product Reports 2005;22(2):269 $-303$

23. Gavamukulya $\mathrm{Y}$, Wamunyokoli $\mathrm{F}$, and El-Shemy HA. Annona muricata: Is the natural therapy to most disease conditions including cancer growing in our backyard? A systematic review of its research history and future prospects. Asian Pacific journal of tropical medicine 2017.

24. Jolad SD, Hoffmann JJ, Schram KH, et al. Uvaricin, a new antitumor agent from Uvaria accuminata (Annonaceae). Journal of Organic Chemistry 1982;47(16):3151-3153.

25. Zafra-Polo MC, González MC, Estornell E, et al. Acetogenins from Annonaceae, inhibitors of mitochondrial complex I. Phytochemistry 1996;42(2):253-271.

26. Sun S, Liu J, Zhou N, et al. Isolation of three new annonaceous acetogenins from Graviola fruit (Annona muricata) and their antiproliferation on human prostate cancer cell PC3. Bioorganic and Medicinal Chemistry Letters 2016;26(17):4382-4385.

27. Sun $\mathrm{S}$, Liu J, Kadouh $\mathrm{H}$, et al. Three new antiproliferative Annonaceous acetogenins with a mono-tetrahydrofuran ring from graviola fruit (Annona muricata). Bioorganic \& medicinal chemistry letters 2014;24(12):2773-2776.

28. Melot A, Fall D, Gleye C, et al. Apolar Annonaceous acetogenins from the fruit pulp of Annona muricata. Molecules 2009;14(11):43874395.

29. Siegel RL, Miller KD, \& Jemal A. Cancer statistics, 2018. CA: A cancer journal for clinicians 2018; 68:7-30.

30. Dai Y, Hogan S, Schmelz EM, et al. Selective growth inhibition of human breast cancer cells by graviola fruit extract in vitro and in vivo involving downregulation of EGFR expression. Nutrition and cancer 2011;63 (5):795-801.

31. Paul J, Gnanam R, M Jayadeepa R, et al. Anticancer activity on Graviola, an exciting medicinal plant extract vs. various cancer cell lines and a detailed computational study on its potent anti-cancerous leads. Current topics in medicinal chemistry 2013;13(14):1666-1673.

32. Liaw CC, Chang FR, Lin CY, et al. New cytotoxic monotetrahydrofuran Annonaceous Acetogenins from Annona muricata. Journal of 
natural products 2002;65(4):470-475.

33. Torres MP, Rachagani S, Purohit V, et al. Graviola: a novel promising natural-derived drug that inhibits tumorigenicity and metastasis of pancreatic cancer cells in vitro and in vivo through altering cell metabolism. Cancer letters 2012;323(1):29-40.

34. Lannuzel A, Michel PP, Ho^ glinger GU, et al. The mitochondrial complex I inhibitor annonacin is toxic to mesencephalic dopaminergic neurons by impairment of energy metabolism. Neuroscience 2003;121 (2):287- 296.

35. Yang $\mathrm{H}$, Liu $\mathrm{N}$, Lee $\mathrm{S}$. Ethanol extract of Annona muricata $\mathrm{L}$ induces liver cancer cell apoptosis through ROS pathway. Biomedical and Pharmacology Journal 2016;9(3):919-925.

36. Chomova $M$, and Racay P. Mitochondrial complex I in the network of known and unknown facts. Gen Physiol Biophys 2010;29 (1):3-11.

37. Moghadamtousi SZ, Karimian H, Rouhollahi E, et al. Annona muricata leaves induce G 1 cell cycle arrest and apoptosis through mitochondria-mediated pathway in human HCT-116 and HT-29 colon cancer cells. Journal of ethnopharmacology 2014; 156:277-289.

38. Green DR, and Kroemer G. The pathophysiology of mitochondrial cell death. Science 2004;305(5684):626-629.

39. McLaughlin JL. Paw Paw and cancer: Annonaceous Acetogenins from discovery to commercial products . Journal of Natural Products 2008;71(7):1311-1321.

40. Elisya Y, Kardono LB, and Simanjuntak P. Tablet formulation of the ethyl acetate soluble extract of soursop (Annona muricata L.) leaves. Asian J. Appl. Sci 2014; 2:323-329.

41. Ko YM, Wu TY, Wu YC, et al. Annonacin induces cell cycle-dependent growth arrest and apoptosis in estrogen receptor-a-related pathways in MCF-7 cells. Journal of Ethnopharmacology 2011;137(3):1283-1290.

42. Wang LQ, Min BS, Li Y, et al. Annonaceous acetogenins from the leaves of Annona montana. Bioorganic \& medicinal chemistry 2002;10(3):561-565.

43. Caparros-Lefebvre D, and Elbaz A. Possible relation of atypical parkinsonism in the French West Indies with consumption of tropical plants: a case-control study. The Lancet 1999;354(9175):281-286.
44. Escobar-Khondiker M, Höllerhage M, Muriel MP, et al. Annonacin, a natural mitochondrial complex I inhibitor, causes tau pathology in cultured neurons. Journal of Neuroscience 2007;27(29):7827-7837.

45. Bonneau N, Le Ven J, Schmitz-Afonso I, et al. Annonaceous acetogenins as environmental neurotoxins: Human exposure from edible annona fruits. Planta Medica 2012;78(11): $\mathrm{PH} 25$.

46. Champy $\mathrm{P}$, Melot A, Guérineau Eng $\mathrm{V}$, et al. Quantification of acetogenins in Annona muricata linked to atypical parkinsonism in Guadeloupe. Movement Disorders 2005;20 (12):1629-1633.

47. Muangpaisan W, Hori $\mathrm{H}$, and Brayne C. A systematic review of the prevalence and incidence of Parkinson's disease in Asia. Journal of Epidemiology 2009;19(6):281-293.

48. Awodele O, Ishola IO, Ikumawoyi VO, et al. Toxicological evaluation of the lyophilized fruit juice extract of Annona muricata Linn (Annonaceae) in rodents. Journal of basic and clinical physiology and pharmacology 2014;25 (4):411-421 